\title{
Use of Box-Behnken design for optimization of compounded medication: acyclovir capsules report
}

\author{
Suelen da Silva Reis ${ }^{\mathrm{a}}$, Valdemir da Silva Quintanilha Junior ${ }^{\mathrm{a}}$, Gabriella da Silva Boto ${ }^{\mathrm{a}}$, Thalita Martins da \\ Silva $^{\mathrm{b}}$, Elizabeth Valverde Macedo ${ }^{\mathrm{a}, \mathrm{b}}$, Carlos Augusto de Freitas Peregrino ${ }^{\mathrm{a}, \mathrm{b}}$, Samanta Cardozo Mourão ${ }^{\mathrm{a}}$, \\ Emeli Moura de Araújo*a \\ ${ }^{a}$ Departamento de Tecnologia Farmacêutica, Faculdade de Farmácia, Universidade Federal Fluminense, Niterói, RJ, \\ Brazil; ' Laboratório Universitário Rodolpho Albino, Universidade Federal Fluminense, Niterói, RJ, Brazil \\ *Corresponding author: emeliaraujo@id.uff.br
}

\begin{abstract}
Campus compounding pharmacies play an important role in public health. Herpes simplex is one of the most common viral diseases in humans, which generates a great demand for acyclovir capsules in compounding pharmacy. It is well known that the formulation's components influence the effectiveness of the drug. The objective of this study is to show the applicability of Box-Behnken design in optimization of a compounded formulation and to evaluate the effect of excipients on dissolution and drug content in acyclovir $200 \mathrm{mg}$ capsules produced at UFF's University Pharmacy (FAU). The formulations were prepared and evaluated for average weight test, uniformity of dosage units and in vitro dissolution, while meeting pharmacopoeial specifications. A statistical analysis showed that sodium starch glycolate, Aerosil@, influences drug content and dissolution results. Magnesium stearate shows no influence on the dissolution at different concentrations but influences the assay results. A numerical optimization was applied to adjust the formulation variables based on the foresaid responses, accomplishing the best formulation that will be prepared and dispensed at FAU upon medical prescription.
\end{abstract}

Keywords: Acyclovir. Dissolution. Excipients. Design of experiment. Capsules.

https://doi.org/10.22456/2527-2616.113283

\section{Introduction}

Campus compounding pharmacies are important sources of medicines at low cost and individualized therapy, always ensuring the quality of the products dispensed. The current legislation for compounding pharmacies (1) requires, as far as capsules quality control test is concerned, weight determination, standard deviation, and relative standard deviation. These analyses establish whether there was a uniform distribution of the powder mixture in the analyzed batch. On the other hand, they do not provide any information on the homogeneity of the encapsulated powder mixture. Therefore, it is feasible that a particular formulation meets the pharmacopeial acceptance criteria for the average weight and, at the same time, falls on non-conformity for the content uniformity test and in vitro dissolution test, which are important parameters for quality assessment of oral solid dosage form (2).

Process or formulation variables could impact the medicine quality, the optimization of these parameters could be carried out using the Design of Experiments (DoE) approach.

DoE is a part of quality by design and can be used to generate design space, which determines the multidimensional combination and interaction of independent variables that have been demonstrated to provide a product of desired quality (3). The Box-Behken technique is capable of analyzing different variables and of helping to select the optimal composition with minimum number of experiments, saving time and resources $(3,4)$.
The University Pharmacy of Fluminense Federal University (FAU), founded in 1996, has a respectful track record in compounding pharmacy including the production of liquid, semi-solid dosage forms and capsules. Currently, it has been reformulating its products to optimize quality parameters, including acyclovir capsules.

Acyclovir (Figure 1) is an antiviral drug that is primarily used for the treatment of Herpes simplex virus (HSV) as well as infections due to Varicella zoster and Herpes zoster virus. It is a guanosine analogue with a functional aliphatic group that is present in the side chain responsible for stopping the virus replication process and competitively inhibiting the viral DNA synthesis. Due to its potent selectivity, it is currently the antiviral of choice for the treatment of the different forms of herpetic infection produced by HSV-1 and HSV-2 (5).

The available dosage forms of acyclovir are capsules, tablets, suspension, and topical ointment (6) being included on the World Health Organization's (WHO) list of essential medicines needed in basic health system (7). The demand for acyclovir capsules in the FAU has been increasing since the compounding allows the supply of medicines in individualized formulations at a lower cost (8). The present work aimed to optimize the FAU's acyclovir formulation based in DoE and considering the effect of excipients on pharmacopeial quality. Furthermore, to show the applicability of Box-Behnken design in the development of formulations in compounding pharmacies, taking advantage of its reduced number of experiments. 
Reis SS et al. / Drug Anal. Res., v. 5, n. 1, p. 59-67, 2021<smiles>Nc1nc(=O)c2ncn(COCCO)c2[nH]1</smiles>

Figure 1. Molecular structure of acyclovir.

\section{Experimental section}

\section{Chemicals and reagents}

Acyclovir (Fragon, Brazil), colloidal silicon dioxide Aerosil@ (Farmos, Brazil), magnesium stearate (Farmos, Brazil), sodium starch glycolate (Blanver, Brazil), microcrystalline cellulose (Galena, Brazil), sodium hydroxide (Vetec, Brazil), hydrochloric acid (Proquimos, Brazil), acetic acid (Synth, Brazil). Deionized water was obtained from the water deionizer Gehaka model 0510LX (Gehaka, São Paulo - 96 Brazil).

\section{Experimental design}

A Box-Behnken factorial design with three variables in three levels was used to study, to optimize, and to evaluate the main effects, namely, interaction, and quadratic effects of the selected independent variables on the response variables.

The Box-Behnken was carried out in Statistica 12.5 Software to evaluate the effects of the independent variables on the in vitro dissolution test and assay of 200 mg acyclovir capsules. All the experimental tests were carried out at the University Laboratory Rodolpho Albino (LURA / UFF).

Selection of excipients and their amounts was based on FAU's original formulation of $200 \mathrm{mg}$ acyclovir capsules, composed of Aerosil® (0.5\%) and magnesium stearate (1\%). Sodium starch glycolate was chosen as a disintegrating agent and it is commonly used in concentrations between $2 \%$ and $8 \%$, with the optimum concentration about $4 \%$ in oral solid dosage forms (9). The independent variables studied were the excipients in different concentrations: A) Aerosil@, B) magnesium stearate, C) sodium starch glycolate. Each independent variable level was expressed by $(-1)$ for the low level, (0) for the medium and (1) for the high level as shown in Table 1. The influence of each excipient in the formulation's performance was evaluated using the absence of each one in the low level (-1). Table 2 presents the matrix factorial design that includes 15 formulations. Formulation 7 is the original formula, and the central point was made in triplicate. The effect of the variables on the acyclovir dissolution and assay were studied (response variable).
Table 1. Levels decoded of independent variables used in DoE.

\begin{tabular}{lccc}
\hline \multirow{2}{*}{ Variables } & \multicolumn{3}{c}{ Level / \% p/p } \\
\cline { 2 - 4 } & Low (-1) & Middle (0) & High (+1) \\
\cline { 2 - 4 } $\begin{array}{l}\text { Sodium starch } \\
\text { glycolate }\end{array}$ & 0 & 4 & 8 \\
$\begin{array}{l}\text { Aerosil@ } \\
\begin{array}{l}\text { Magnesium } \\
\text { stearate }\end{array}\end{array}$ & 0 & 0.5 & 1 \\
\hline
\end{tabular}

Table 2. Matrix factorial design of acyclovir capsules.

\begin{tabular}{cccc}
\hline & \multicolumn{3}{c}{ Excipients $(\% \mathbf{p} / \mathbf{p})$} \\
\cline { 3 - 4 } Formulation & $\begin{array}{c}\text { Sodium } \\
\text { starch } \\
\text { glycolate }\end{array}$ & Aerosil® & $\begin{array}{c}\text { Magnesium } \\
\text { stearate }\end{array}$ \\
\cline { 2 - 4 } 2 & 0 & 0 & 0.5 \\
3 & 8 & 0 & 0.5 \\
4 & 0 & 1 & 0.5 \\
5 & 8 & 1 & 0.5 \\
6 & 0 & 0.5 & 0 \\
7 & 8 & 0.5 & 0 \\
8 & 0 & 0.5 & 1 \\
9 & 8 & 0.5 & 1 \\
10 & 4 & 0 & 0 \\
11 & 4 & 1 & 0 \\
12 & 4 & 0 & 1 \\
13 & 4 & 1 & 1 \\
14 & 4 & 0.5 & 0.5 \\
15 & 4 & 0.5 & 0.5 \\
\hline
\end{tabular}

Each formulation contained acyclovir $0.1992 \mathrm{~g}$ (equivalent to $0.2 \mathrm{~g}$ of acyclovir) and the excipient quantitative composition was described in Table 2. Microcrystalline cellulose was used as a diluent in quantum satis (q.s.) to complete each capsule volume, with values corresponding from 45,21 to $55,39 \%$ of the concentration (w/w), depending on the formulation. The powder mixtures were prepared by manually mixing in geometric dilution, then filled into size 00 capsules (10). A total of sixty (60) capsules were obtained in each experiment.

The response variables used for optimization of the formulation were average weight, acyclovir content and amount dissolved at 45 minutes from dissolution test.

The results were expressed as mean \pm standard deviation (SD) using Microsoft Excel software (Redmond, WA, USA). The statistical analysis was performed by analysis of variance (ANOVA) using Statistica 12.5 Software, and the results were compared graphically by Pareto chart of standardized effects and by 3D response surface plot generated by the software. Significance level was considered at $\mathrm{p}<0.05$.

\section{Average weight}

The weight determination was carried out by using 20 units, according to Brazilian Pharmacopoeia 6th edition (11) method. The average weight was calculated by comparing the difference between full and empty capsules. The 
uniformity of weight was evaluated based on variation limits for the average weights present in the Brazilian Pharmacopeia. The standard deviation and relative standard deviation were calculated. It was considered $7.5 \%$ (more or less) as a variation limit (11).

\section{Acyclovir content}

The concentration of acyclovir was determined by UV spectrophotometry (Perkin Elmer, Model: Lambda 35 UV/VIS Spectrometer) following the method uniformity of dosage units by weight variation, as described in Brazilian Pharmacopeia 6th edition (12). Twenty individual capsules were accurately weighed (Shimadzu, Model: AUY220) before and after removing their content, then the average weight was recorded. The content of the capsules were triturated by using mortar and pestle where the equivalent of $0.1 \mathrm{~g}$ of acyclovir was transferred to a $100 \mathrm{~mL}$ volumetric flask. Then, $60 \mathrm{~mL}$ of a sodium hydroxide $0.1 \mathrm{M}$ solution was added and put into sonication for 15 minutes without heating. Thereafter, the flask was completed with $0.1 \mathrm{M} \mathrm{NaOH}$, homogenized and filtered. Then $15 \mathrm{~mL}$ of this solution was transferred to a $100 \mathrm{~mL}$ volumetric flask, adding $5.8 \mathrm{~mL} 2 \mathrm{M}$ hydrochloric acid and $50 \mathrm{~mL}$ deionized water, homogenized and the flask was filled with deionized water. Subsequently, $5 \mathrm{~mL}$ was transferred to a $50 \mathrm{~mL}$ volumetric flask and filled with acetic acid $0.1 \mathrm{M}$. The absorbance at $255 \mathrm{~nm}$ was determined using $0.1 \mathrm{~N}$ hydrochloric acid as blank. A calibration curve, ranging from 5 to $18 \mu \mathrm{g} / \mathrm{ml}$, was constructed by the absorbances at $255 \mathrm{~nm}$ using $0.1 \mathrm{~N}$ hydrochloric acid as solvent ( $\mathrm{y}=$ $\left.56624 x+0.0176 ; R^{2}=0.9940\right)$.

\section{Dissolution tests}

The dissolution tests were carried out in a dissolution tester (Nova Etica, Model 299) according to the acyclovir capsules monograph of U.S. Pharmacopoeia (USP) (13): apparatus 1 (basket), speed of $100 \mathrm{rpm}, 900 \mathrm{~mL}$ of $0.1 \mathrm{~N}$ hydrochloric acid solution at $37 \pm 0.5^{\circ} \mathrm{C}$. The filtered aliquots of $1 \mathrm{~mL}$ were removed from each vessel at 45 minutes, transferred to $10 \mathrm{~mL}$ volumetric flask and filled with $0.1 \mathrm{~N}$ hydrochloric acid.

The absorbance at $254 \mathrm{~nm}$ was determined by UV spectrophotometry (Perkin Elmer, Model: Lambda 35 UV/VIS Spectrometer) using $0.1 \mathrm{~N}$ hydrochloric acid as blank. USP (13) recommends not less than $75 \%$ of acyclovir dissolved in 45 minutes of test. The same calibration curve described in acyclovir content section was used.

The dissolution results obtained were the variables of the experimental planning and were analyzed in Statistica 12.5 Software, performing ANOVA followed Tukey's post-hoc test.

\section{Optimization of formulation using desirability approach}

In Statistica 12.5 Software, numerical optimization was applied to optimize the formulation variables based on the aforesaid responses.

Three formulations were prepared using the predicted values and desirability for the dissolution (FA), acyclovir content (FB) and the original FAU's formulation (FC). The dissolution profile was determined for each formulation, for this test it was used the same conditions and method described above (13), but $1 \mathrm{~mL}$ were removed from each vessel at $5,10,15,20,30,45$ and 60 minutes, with immediate replacement of fresh medium to keep the balance of the sink condition (14). Thereafter, the samples were filtered, and the percentages of drug dissolved were determined in a UV spectrophotometer (Perkin Elmer, Model: Lambda 35 UV/VIS Spectrometer) at $254 \mathrm{~nm}$ using $0.1 \mathrm{~N}$ hydrochloric acid as blank. The dissolution profiles were obtained. The same calibration curve described in acyclovir content section was used.

The dissolution efficiencies (DE\%) were determined for the ratio among the area under the dissolution curves, between the times zero and 60 minutes $\left(\mathrm{AUC}_{0-60}\right)$ calculated applying the trapezoidal method, and the total area of the rectangle $\left(\mathrm{AUC}_{\mathrm{TR}}\right)$ defined for the ordinate $(100 \%$ of dissolution) and for the abscissa ( $t=60$ minutes) (15). The statistical analysis of variance (ANOVA) followed Tukey's post-hoc test, using Statistica 12.5 software, was performed considering as significant the values of $\mathrm{p}<0.05$.

\section{Results and Discussion}

All formulations met the requirements for average weight according to the (limit variation of $7.5 \%$ ) preconized by Brazilian Pharmacopoeia 6th edition (11) and showed low relative standard deviation (RSD) values, between 1.35$3.58 \%$ (Table 3).

\section{Influence of independent variables on the acyclovir content}

The 15 formulations proposed in experiment design presented results of drug content ranging between 89.94$100.5 \%$ (Table 4).

The results of acyclovir content were loaded in Statistica 12.5 Software. Figure 2 illustrates the interplay between different factors studied for their effect on acyclovir content. The results were present as the response at different combinations of two variables, keeping the third variable at its middle level.

The three-dimensional response surface curves demonstrate that magnesium stearate shows a positive influence in intermediate concentration, while Aerosil® and sodium starch glycolate in lower or higher concentration (Figure 2). 
Table 3. Average weight of the developed formulations (1-15).

\begin{tabular}{|c|c|c|c|}
\hline $\begin{array}{l}\text { Formula } \\
\text { tion }\end{array}$ & $\begin{array}{c}\text { Average weight (g) } \\
\text { X } \pm \text { S (RSD\%) }\end{array}$ & $\begin{array}{l}\text { Min Value } \\
\text { (IL) }\end{array}$ & $\begin{array}{c}\text { Max Value } \\
\text { (SL) }\end{array}$ \\
\hline 1 & $\begin{array}{c}0.4639 \pm 0.0098 \\
(2.10 \%)\end{array}$ & $\begin{array}{c}0.4390 \\
(0.4291)\end{array}$ & $\begin{array}{c}0.4790 \\
(0.4987)\end{array}$ \\
\hline 2 & $\begin{array}{c}0.4768 \pm 0.0151 \\
(3.16 \%)\end{array}$ & $\begin{array}{c}0.4507 \\
(0.4410)\end{array}$ & $\begin{array}{c}0.4982 \\
(0.5125)\end{array}$ \\
\hline 3 & $\begin{array}{c}0.4398 \pm 0.0123 \\
(2.79 \%)\end{array}$ & $\begin{array}{c}0.4140 \\
(0.4068)\end{array}$ & $\begin{array}{c}0.4580 \\
(0.4727)\end{array}$ \\
\hline 4 & $\begin{array}{c}0.4577 \pm 0.0094 \\
(2.05 \%)\end{array}$ & $\begin{array}{c}0.4400 \\
(0.4233)\end{array}$ & $\begin{array}{c}0.4760 \\
(0.4920)\end{array}$ \\
\hline 5 & $\begin{array}{c}0.4527 \pm 0.0090 \\
(1.99 \%)\end{array}$ & $\begin{array}{c}0.4387 \\
(0.4187)\end{array}$ & $\begin{array}{c}0.4680 \\
(0.4866)\end{array}$ \\
\hline 6 & $\begin{array}{c}0.4660 \pm 0.0113 \\
(2.42 \%)\end{array}$ & $\begin{array}{c}0.4434 \\
(0.4310)\end{array}$ & $\begin{array}{c}0.4898 \\
(0.5009)\end{array}$ \\
\hline 7 & $\begin{array}{c}0.4516 \pm 0.0161 \\
(3.58 \%)\end{array}$ & $\begin{array}{c}0.4290 \\
(0.4177)\end{array}$ & $\begin{array}{c}0.4780 \\
(0.4854)\end{array}$ \\
\hline 8 & $\begin{array}{c}0.4660 \pm 0.0101 \\
(2.17 \%)\end{array}$ & $\begin{array}{c}0.4490 \\
(0.4311)\end{array}$ & $\begin{array}{c}0.4860 \\
(0.5010)\end{array}$ \\
\hline 9 & $\begin{array}{c}0.4724 \pm 0.0141 \\
(2.98 \%)\end{array}$ & $\begin{array}{c}0.4460 \\
(0.4369)\end{array}$ & $\begin{array}{c}0.4980 \\
(0.5078)\end{array}$ \\
\hline 10 & $\begin{array}{c}0.4445 \pm 0.0051 \\
(1.16 \%)\end{array}$ & $\begin{array}{c}0.4350 \\
(0.4112)\end{array}$ & $\begin{array}{c}0.4520 \\
(0.4778)\end{array}$ \\
\hline 11 & $\begin{array}{c}0.4715 \pm 0.0099 \\
(2.11 \%)\end{array}$ & $\begin{array}{c}0.4550 \\
(0.4361)\end{array}$ & $\begin{array}{c}0.4870 \\
(0.5068)\end{array}$ \\
\hline 12 & $\begin{array}{c}0.4447 \pm 0.0108 \\
(2.42 \%)\end{array}$ & $\begin{array}{c}0.4130 \\
(0.4113)\end{array}$ & $\begin{array}{c}0.4580 \\
(0.4780)\end{array}$ \\
\hline 13 & $\begin{array}{c}0.4552 \pm 0.0110 \\
(2.41 \%)\end{array}$ & $\begin{array}{c}0.4390 \\
(0.4211)\end{array}$ & $\begin{array}{c}0.4810 \\
(0.4893)\end{array}$ \\
\hline 14 & $\begin{array}{c}0.4587 \pm 0.0081 \\
(1.76 \%)\end{array}$ & $\begin{array}{c}0.4440 \\
(0.4243)\end{array}$ & $\begin{array}{c}0.4730 \\
(0.4930)\end{array}$ \\
\hline 15 & $\begin{array}{c}0.4571 \pm 0.0061 \\
(1.35 \%)\end{array}$ & $\begin{array}{c}0.4460 \\
(0.4228)\end{array}$ & $\begin{array}{c}0.4700 \\
(0.4914)\end{array}$ \\
\hline
\end{tabular}

$\mathrm{X}=$ average, $\mathrm{S}=$ standard deviation, $\mathrm{RSD}=$ relative standard deviation, Max value $=$ maximum value of weight; Min value $=$ minimum value of weight $(n=20)$, SL $=$ superior weight variation limit, $\mathrm{IL}=$ inferior weight variation limit.

Table 4. Acyclovir content of the developed formulations (1-15)

\begin{tabular}{cc}
\hline Formulation & $\begin{array}{c}\text { Acyclovir content }(\%) \\
\mathbf{X} \pm \mathbf{S}(\mathbf{R S D})\end{array}$ \\
\hline 1 & $98.68 \pm 0.62(0.63 \%)$ \\
2 & $98.13 \pm 1.27(1.29 \%)$ \\
3 & $97.17 \pm 8.00(8.24 \%)$ \\
4 & $100.5 \pm 1.81(1.79 \%)$ \\
5 & $96.65 \pm 3.10(3.21 \%)$ \\
6 & $92.91 \pm 2.23(2.40 \%)$ \\
7 & $93.26 \pm 3.44(3.69 \%)$ \\
8 & $91.97 \pm 2.36(2.57 \%)$ \\
9 & $92.72 \pm 2.76(2.97 \%)$ \\
10 & $92.18 \pm 3.46(3.75 \%)$ \\
11 & $89.94 \pm 4.44(4.94 \%)$ \\
12 & $90.53 \pm 4.03(4.46 \%)$ \\
13 & $90.17 \pm 3.79(4.21 \%)$ \\
14 & $91.02 \pm 4.85(5.32 \%)$ \\
15 & $91.32 \pm 3.22(3.53 \%)$ \\
\hline
\end{tabular}

$\mathrm{X}=$ average, $\mathrm{S}=$ standard deviation, $\mathrm{RSD}=$ relative standard deviation.

Pareto charts were plotted to represent ANOVA tests and determine the effect of the independent variables, their interactions, and their quadratic effects on the dependent variables. Positive (+) and negative (-) coefficients show the synergistic effect and the antagonistic effect, respectively (14). Pareto chart (Figure 3) corroborate that sodium starch glycolate and Aerosil ${ }^{\circledR}$ have a negative quadratic influence on the assay, while magnesium stearate has a quadratic and linear influence on the result, with pvalues lower than 0.05 (Figure 3).

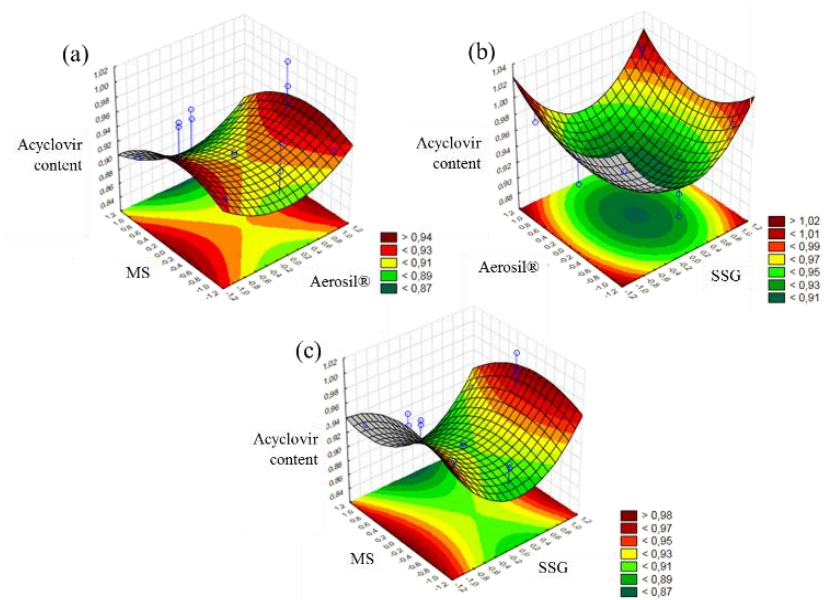

Figure 2. Response surface plots showing the effect of the three variables on the acyclovir content: (a) the effect of magnesium stearate and Aerosil ${ }^{\circledR}$; (b) the effect of Aerosil ${ }^{\circledR}$ and sodium starch glycolate; (c) the effect of magnesium stearate and sodium starch glycolate. $\mathrm{MS}=$ magnesium stearate, $\mathrm{SSG}=$ sodium starch glycolate.

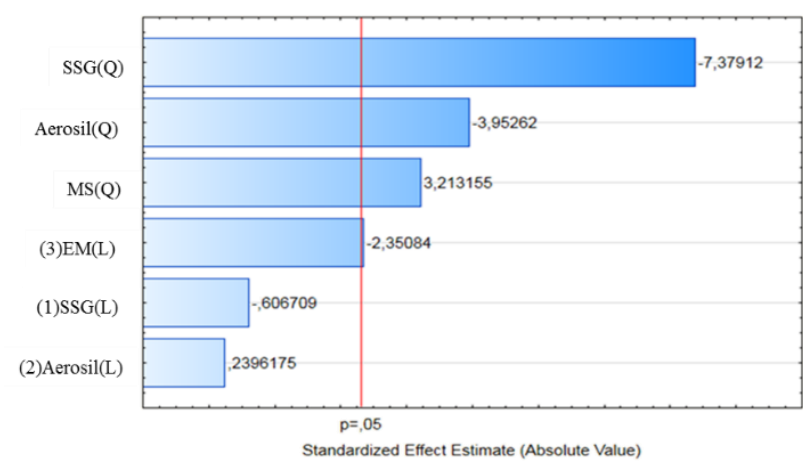

Figure 3. Pareto chart of standardized effects for acyclovir content. MS = magnesium stearate, $\mathrm{SSG}=$ sodium starch glycolate, $\mathrm{Q}=$ quadratic, $\mathrm{L}=$ Linear.

\section{Influence of independent variables on the dissolution test}

All formulations met the requirements for dissolution test of USP 44 (13), where not less than $75 \%$ was dissolved in 45 minutes of testing, with values between $83-91 \%$ of acyclovir dissolved in 45 min (Table 5).

The data from the 15 formulations (Table 5) were analyzed in the Statistica 12.5 Software. Figure 4 illustrates the interplay between the variables studied and their effect on acyclovir dissolution. The three-dimensional response surface curves demonstrate that magnesium stearate show no influence on the dissolution at different concentrations, while sodium starch glycolate at medium concentration and Aerosil ${ }^{\circledR}$ at higher concentration displayed higher dissolution results (Figure 4). 
Table 5. Percentages of acyclovir dissolved for the developed formulations (1-15).

\begin{tabular}{cc}
\hline Formulation & $\begin{array}{c}\text { Acyclovir dissolved }(\%) \\
\mathbf{X} \pm \mathbf{S}(\mathbf{R S D} \%)\end{array}$ \\
\hline 1 & $90.57 \pm 0.028(3.07 \%)$ \\
2 & $89.37 \pm 0.033(3.66 \%)$ \\
3 & $90.98 \pm 0.032(3.55 \%)$ \\
4 & $88.51 \pm 0.021(2.39 \%)$ \\
5 & $88.66 \pm 0.020(2.29 \%)$ \\
6 & $89.21 \pm 0.033(3.70 \%)$ \\
7 & $89.01 \pm 0.046(5.14 \%)$ \\
8 & $88.58 \pm 0.011(1.26 \%)$ \\
9 & $90.69 \pm 0.040(4.45 \%)$ \\
10 & $90.42 \pm 0.017(1.84 \%)$ \\
11 & $88.99 \pm 0.023(2.62 \%)$ \\
12 & $91.50 \pm 0.023(2.56 \%)$ \\
13 & $90.87 \pm 0.025(2.75 \%)$ \\
14 & $91.05 \pm 0.027(2.91 \%)$ \\
15 & $91.04 \pm 0.025(2.76 \%)$ \\
\hline
\end{tabular}

$\mathrm{X}=$ average, $\mathrm{S}=$ standard deviation, $\mathrm{RSD}=$ relative standard deviation.

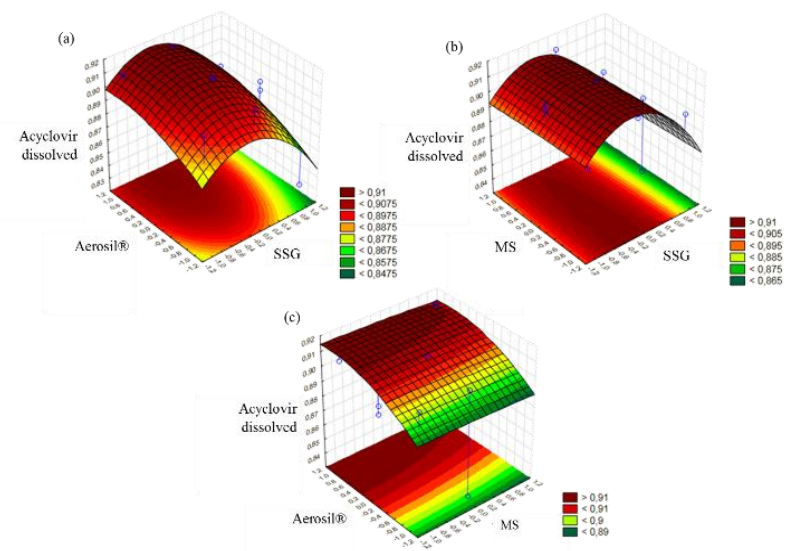

Figure 4. Response surface plots showing the effect of the three variables on the acyclovir dissolved: (a) the effect of Aerosil and sodium starch glycolate; (b) the effect of magnesium stearate and sodium starch glycolate; (c) the effect of Aerosil@ and magnesium stearate. $\mathrm{MS}=$ magnesium stearate, $\mathrm{SSG}=$ sodium starch glycolate.

Figure 5 shows ANOVA tests represented by Pareto chart and corroborates that sodium starch glycolate generates a statistically significant influence on the percentage of dissolved acyclovir ( $\mathrm{p}$-value $<0.05$ ), influencing the dissolution in a quadratic way through the interaction with the other excipients of the formulation.

DoE has been widely used in the pharmaceutical industry for research and development of formulations. The statistical design for empirical experiments leads to more reliable results, saving time and reduction of number repetitions of the experiments. The response surface methodology studies the relationship between the response and their effective factors where regression models are used for analyzing the response. The experiments in this methodology study the effects of various factors and evaluate obtaining the optimal conditions to achieve the desired response. The most common model of this method is Box-Behnken, that is a spherical design and is also utilized for the optimization (14).

Previous works have demonstrated the applicability of BoxBehnken design to observe the excipients' effect on formulation. Dayal et al. (2005) (16) studied the effect of excipients on properties of nasal drug delivery system hydroyiureia- contains. Using Box-Behnken experimental design, it was possible to predict and to indentify the major excipients that influences product quality.

In other study, the experimental design was used to optimize and evaluate of excipients (crosslinked caboxymethyl cellulose, sodium starch glycolate and starch) on domperidone maleate release from tablets, considering the main, interaction and quadratic effects. After statistical analyses it was observed the increase of dissolution using the combination of carboxymethyl cellulose and sodium starch glycolate (17).

In the same way, in development of fast dissolving tablets, the Box-Benken design allow to predict an optimal formulation, considering excipients kinds and concentrations, from evaluation of variables interactions (18).

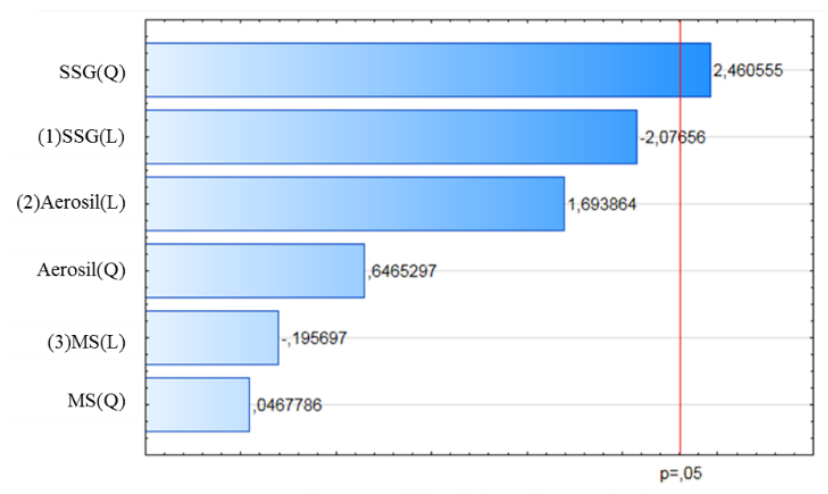

Figure 5. Pareto chart of standardized effects for acyclovir dissolved. $\mathrm{MS}=$ magnesium stearate, $\mathrm{SSG}=$ sodium starch glycolate, $\mathrm{Q}=$ quadratic, $\mathrm{L}=$ Linear.

\section{Optimization of formulation using desirability approach}

The purpose of the optimization step is to determine the ideal level of each independent variable to prepare a product with the best quality attributes (3). In the present study, the main desirable outcome is to provide an acyclovir formulation with the best dissolution profile. In Statistica 12.5 Software, numerical optimization was applied to improve the formulation variables based on the aforesaid responses.

Figure 6 demonstrates that the highest value of desirability for the acyclovir content $(0.99145)$ could be achieved at low level $(-1)$ of sodium starch glycolate $(0 \%)$, higher level $(+1)$ of Aerosil® (1\%) and medium level $(-0.2)$ of magnesium stearate $(0.4 \%)$. 


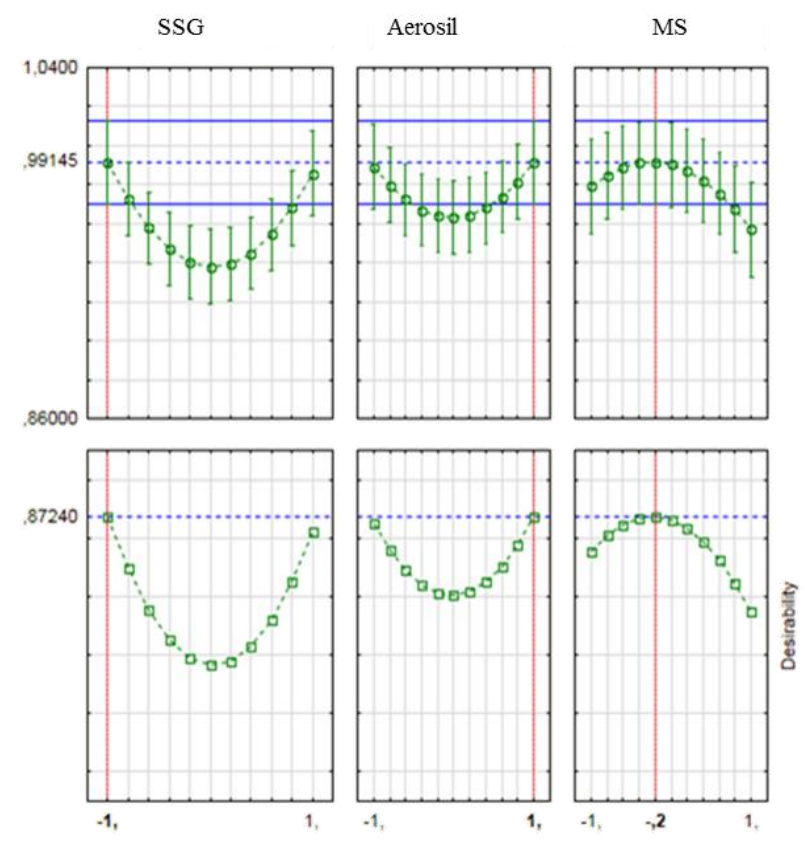

Figure 6. Graphical representation of predicted and desirability values profile for acyclovir content. MS = magnesium stearate, $\mathrm{SSG}=$ sodium starch glycolate.

Figure 7 demonstrates that the highest value of desirability for the acyclovir dissolution (0.95906) could be attained at medium level $(-0.2)$ of sodium starch glycolate $(3.2 \%)$, higher level $(+1)$ of Aerosil® $(1 \%)$ and medium level $(+0.4)$ of magnesium stearate $(0.7 \%)$.

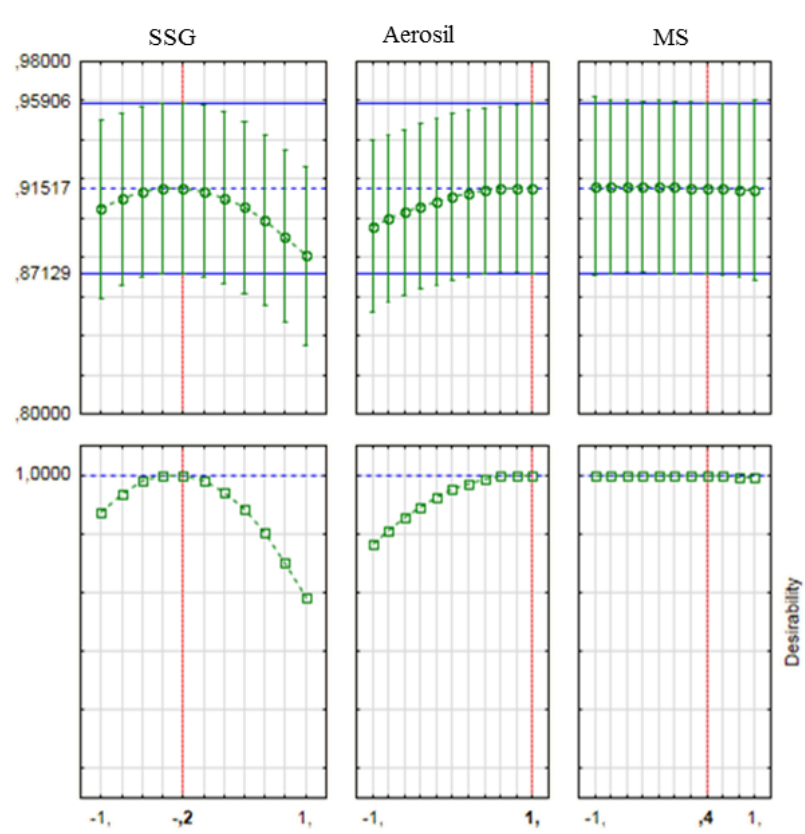

Figure 7. Graphical representation of predicted and desirability values profiles for acyclovir dissolution. MS = magnesium stearate, $\mathrm{SSG}=$ sodium starch glycolate.

The theoretical formulations for dissolution (FA), acyclovir content (FB) and the original formulation (FC) (Table 6) were prepared, and the dissolution profile determined. As described in a previous section, the microcrystalline cellulose was applied as q.s. acting as a diluent in each formulation.

Table 6. Compositions of the theoretical formulations.

\begin{tabular}{|c|c|c|c|}
\hline \multirow[t]{2}{*}{ Component } & \multicolumn{3}{|c|}{ Percentage (\%) } \\
\hline & FA & FB & FC \\
\hline Acyclovir & $\begin{array}{c}48.16 \\
(0.1992 \mathrm{~g})\end{array}$ & $\begin{array}{c}49.46 \\
(0.1992 \mathrm{~g})\end{array}$ & $\begin{array}{c}49.98 \\
(0.1992 \mathrm{~g})\end{array}$ \\
\hline SSG & 3.2 & - & - \\
\hline Aerosil & 1 & 1 & 0.5 \\
\hline MS & 0.7 & 0.4 & 1 \\
\hline MC & 45.48 & 48.5 & 50.25 \\
\hline
\end{tabular}

MS = magnesium stearate, $\mathrm{SSG}=$ sodium starch glycolate; $\mathrm{MC}=$ microcrystalline cellulose.

Acyclovir is one of the most important antiviral drugs but has several problems due to its physical properties (19). The oral bioavailability of acyclovir is about $20 \%$ with an elimination half-life of $1-2 \mathrm{~h}$. The drug has a narrow absorption window and is primarily absorbed from the region of stomach and upper portion of the small intestine (4). Solubility, permeability, and drug product dissolution determine the rate and extent of drug absorption from immediate-release solid oral dosage forms, such as tablets and capsules (20).

The dissolution performance is one of the most relevant parameters in a formulation evaluation as it governs the release rate of the drug from the solid form and hence its bioavailability (3).

The dissolution study refers to the evaluation of the position change of the solute molecule from its original and interacting environment, to a liquid environment with different molecules, providing information on the drug's in vivo behavior, since the absorption speed is linked to the dissolution process, reflecting its characteristics of quality and bioavailability (21).

Several factors can influence these characteristics, including the choice of excipients such as lubricants and disintegrants that will provide the formulation with good fluidity and uniform sizing, as well as allowing adequate conditions for the drug to dissolve, respectively (22). In this sense the excipients study is particularly important, since their choice can change both positively and negatively, as an example, the high hydrophobicity of one of these excipients leads to difficulty in wetting and reducing its dissolution rate.

They also influence the handling process, considering the mixing operations, the care with previously mixed powders so that they do not suffer segregation during their handling, and the flow of the powder into the capsules and their leveling, processes that can change the uniformity of the final product (23).

The dissolution test was carried out to evaluate and compare the release profiles of acyclovir from different formulations FA, FB and FC (Table 6). The dissolution profiles of each formulation are summarized in Figure 8. Similar results were found for three formulations. 


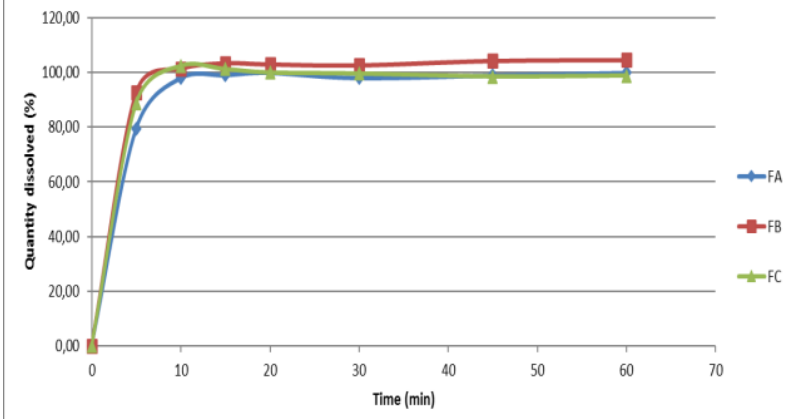

Figure 8. Acyclovir formulations dissolution profile in formulations (FA), (FB) and (FC).

The dissolution efficiency (DE) can be used to compare the dissolution profiles. The results of DE confirm the profiles graphical analysis (Figure 8) and the values (Table 7). The results were compared using ANOVA followed by Tukey's post-hoc test and indicates that there are no differences between the dissolution profiles of the 3 formulations.

The requirements for dissolution test is not less than $75 \%$ of acyclovir dissolved in 45 minutes of testing (13), in this study more than $75 \%$ of acyclovir was released within 5 min for formulations A, B and C (Table 8).

Table 7. DE values (\%) of acyclovir formulations (FA), (FB) and (FC).

\begin{tabular}{cc}
\hline Formulation & DE (\%) \\
& $\mathbf{X} \pm \mathbf{S}(\mathbf{R S D} \%)$ \\
\hline $\mathrm{A}$ & $68.29 \pm 1.62(2.37 \%)$ \\
$\mathrm{B}$ & $72.08 \pm 1.02(1.41 \%)$ \\
$\mathrm{C}$ & $69.86 \pm 2.77(3.96 \%)$ \\
\hline
\end{tabular}

$\mathrm{X}=$ average, $\mathrm{S}=$ standard deviation, $\mathrm{RSD}=$ relative standard deviation.

Table 8. Quantity dissolved (Q) of acyclovir in formulations (FA), (FB) and (FC) at 5 and 10 minutes $(n=3)$.

\begin{tabular}{ccc}
\hline Formulation & $\begin{array}{c}\text { Q 5min (\%) } \\
\text { X } \pm \text { S (RSD\%) }\end{array}$ & $\begin{array}{c}\text { Q 10min (\%) } \\
\text { X } \pm \text { S (RSD\%) }\end{array}$ \\
\hline $\mathrm{A}$ & $79.52^{\mathrm{a}} \pm 0.60(0.76 \%)$ & $97.95^{\mathrm{a}} \pm 3.75(3.82 \%)$ \\
$\mathrm{B}$ & $92.77^{\mathrm{b}} \pm 2.27(2.45 \%)$ & $101.39^{\mathrm{a}} \pm 2.26(2.33 \%)$ \\
$\mathrm{C}$ & $88.68^{\mathrm{b}} \pm 5.54(6.24 \%)$ & $102.29^{\mathrm{a}} \pm 4.59(4.49 \%)$ \\
\hline
\end{tabular}

$\mathrm{a}, \mathrm{b}=$ Same letters in the same column do not show statistically significant differences according to ANOVA and Tukey's posthoc test.

Rapid dissolution requires $>85 \%$ of active ingredients be dissolved in $30 \mathrm{~min}$ (20). More than $97 \%$ of acyclovir was dissolved from formulations $\mathrm{A}, \mathrm{B}$ and $\mathrm{C}$ within $10 \mathrm{~min}$, indicating rapid dissolution (Table 8). If dissolution is very rapid, the limiting step for oral absorption would be intestinal membrane permeation or gastric emptying, and not drug dissolution (20).

Vaithianathan et al. (2016) (20) studied the influence of 14 common excipients in cimetidine and acyclovir capsules. The quantities were higher than those used in typical immediate-release solid oral dosage forms. The dissolution profile and a human pharmacokinetic study was conducted. Through three four-way crossover BE studies, 12 common excipients were found to not impact
BCS class III drug absorption in humans: sodium lauryl sulfate, corn starch, sodium starch glycolate, colloidal silicon dioxide, dibasic calcium phosphate, crospovidone, lactose, povidone, stearic acid, pregelatinized starch, croscarmellose sodium, and magnesium stearate.

Although formulation A contained 3.2\% sodium starch glycolate it showed a theoretical influence on the dissolution of acyclovir (Figure 5), but there was no statistically significant difference in the dissolution profile (Figure 8), DE (Table 7) and in the dissolution in times 5 and 10 minutes (Table 8). Therefore, the addition of this excipient is not necessary in the proposed formulation.

Over-mixing of magnesium stearate is known to slow the dissolution by forming a coating around drug and other excipients dissolution and possibly reduce drug absorption (20). Although formulation $\mathrm{C}$ contains $1 \%$ magnesium stearate, the dissolution profile did not show any statistically significant difference (Table 7) compared to formulation A and $\mathrm{B}$ which contain $0.7 \%$ and $0.4 \%$ magnesium stearate, respectively.

The three formulations also showed no statistically significant difference at times 5 and 10 of dissolution (Table 8 ), showing that this variation from 0.4 to $1 \%$ of magnesium stearate did not impact the dissolution of acyclovir. This corroborates what has been shown in the three-dimensional response surface curves (Figure 4) and Pareto chart (Figure 5) that demonstrate that magnesium stearate shows no influence on the dissolution at different concentrations.

The variation of 0.5 to $1 \%$ of colloidal silicon dioxide (Aerosil@) also did not seem to affect the dissolution rate as shown in tables 7, 8 and figure 8 , which was also shown in figures 4 and 5 .

The theoretical formulations were tested for acyclovir content. USP 44 (13) recommends for acyclovir capsules not less than $93 \%$ of the labeled amount of acyclovir. Only on FB, the theoretical formulation for acyclovir content achieved this minimum result (Table 9). The uniformity of dosage units by weight variation was calculated according to Brazilian Pharmacopoeia (11) and FB achieved the lower acceptance value (7.96) meeting the requirements (AV $\leq$ 15). This formulation was predicted by the software to be the formulation that would have the best results for acyclovir content and was chosen as the optimized formulation to be produced in FAU.

Table 9. Results of acyclovir content for formulations (FA), (FB) and (FC)

\begin{tabular}{cc}
\hline Formulation & $\begin{array}{c}\text { Acyclovir content (\%) } \\
\mathbf{X} \pm \mathbf{S}(\mathbf{R S D} \%)\end{array}$ \\
\hline A & $92.02 \pm 2.38(2.58 \%)$ \\
B & $94.44 \pm 0.22(0.24 \%)$ \\
C & $88.07 \pm 1.54(1.75 \%)$ \\
\hline
\end{tabular}

$\mathrm{X}=$ average, $\mathrm{S}=$ standard deviation, $\mathrm{RSD}=$ relative standard deviation.

\section{Conclusions}

The technique Design of Experiments (DoE) is an excellent tool for evaluating the influence of several parameters 
affecting the formulation at low cost and with small number of experiments. By employing this method, it was possible to evaluate the influence of the excipients on acyclovir $200 \mathrm{mg}$ formulations, and the applicability and robustness of the method was demonstrated by the software prediction of which formulation would generate the best acyclovir content in the capsules, allowing the University Pharmacy (FAU) to offer a pharmaceutical product with higher quality under suitable production process conditions.

\section{Acknowledgments}

Project supported by the Extension Scholarship Program 2017, 2018 and 2019 - Pró-Reitoria de Extensãol Universidade Federal Fluminense (PROEX/UFF). The authors also gratefully acknowledge the help from the colleagues from UFF: Daniela Caldeira Sampaio, Eliana de Vares Cação, Nilo Piccoli and Silvana Maria Vieira Marinho.

\section{Conflict of interest}

The authors declare that there is no conflict of interests regarding the publication of this article.

\section{References}

1. Agência Nacional de Vigilância Sanitária (Anvisa). Resolução RDC n 67 de 08 de outubro de 2007. Dispõe sobre Boas Práticas de Manipulação de Preparações Magistrais e Oficinais para Uso Humano em farmácias DOU. Brasília, Brazil: Diário Oficial da União; 2007. Available at: http://antigo.anvisa.gov.br/documents/10181/271837 6/RDC_67_2007_COMP.pdf/5de28862-e018-4287892e-a2add589ac26. Accessed Mar 29, 2021.

2. Almeida MLC, Filho APN. Análise das cápsulas manipuladas segundo a RDC 67/2007 para a garantia da qualidade. Rev. Bras. de Farm. 2010; 91(3): 11925 .

3. Alalaiwe A, Fayed MH, Alshahrani SM, Alsulays BB, Alshetaili AS, Tawfeek HM, et al. Application of design of experiment approach for investigating the effect of partially pre-gelatinized starch on critical quality attributes of rapid orally disintegrating tablets. J Drug Deliv Sci Technol. 2019; 49: 227-234. ISSN 1773-2247. https://doi.org/10.1016/j.jddst.2018.11.018.

4. Kharia AA, Singhai AK. Development and optimisation of mucoadhesive nanoparticles of acyclovir using design of experiments approach. J Microencapsul. 2015; 32(6):521-32. doi: 10.3109/02652048.2015.1010457. Epub 2015 Aug 18. PMID: 26333938.

5. Maniya NH, Patel SR, Murthy ZVP. Development and in vitro evaluation of acyclovir delivery system using nanostructured porous silicon carriers. Chem. Eng. Res. Des. 2015; 104: 551-557, ISSN 0263-8762. https://doi.org/10.1016/j.cherd.2015.09.008
6. Hassan H, Adam SK, Othman F, Shamsuddin AF, Basir R. Antiviral. Nanodelivery Systems: Current Trends in Acyclovir Administration. J. Nanomater. 2016; 1-8. https://doi.org/10.1155/2016/4591634

7. Al-Subaie MM, Hosny KM, El-Say KM, Ahmed TA, Aljaeid BM. Utilization of nanotechnology to enhance percutaneous absorption of acyclovir in the treatment of herpes simplex viral infections. Int $\mathrm{J}$ Nanomedicine. 2015; 10:3973-85. doi: 10.2147/IJN.S83962.

8. Stulzer HK, Tagliari MP, Silva MAS, Laranjeira MCM. Desenvolvimento, avaliação e caracterização fisicoquímica de micropartículas constituídas de aciclovir/quitosana desenvolvidas pela técnica de spraydrying. Lat Am J Pharm. 2007; 26(6): 866-71. Available from: http://www.latamjpharm.org/Subscription required.

9. Rowe, R. C., Sheskey, P. J., \& Weller, P. J. (2003). Handbook of pharmaceutical excipients. London: Pharmaceutical Press.

10. Pinheiro GM, Benavide VG, Volpato NM, Cabral LM, Santos EP. Indicadores para controle de processo na manipulação de cápsulas em farmácia. Rev. Bras. Farm. 2008; 89(1):28-31. http://www.rbfarma.org.br/files/pag_28a31_indicadore s_capsulas.pdf

11. Brasil. Ministério da Saúde. Agência Nacional de Vigilância Sanitária. Farmacopéia Brasileira, $6^{a}$ edição. v. 1. Brasília: Agência Nacional de Vigilância Sanitária, 2019. http://portal.anvisa.gov.br/farmacopeia-brasileira

12. Brasil. Ministério da Saúde. Agência Nacional de Vigilância Sanitária. Farmacopéia Brasileira, $6^{\mathrm{a}}$ edição. v. 2. Brasília: Agência Nacional de Vigilância Sanitária, 2019. Disponível em < http://portal.anvisa.gov.br/farmacopeia-brasileira

13. United States Pharmacopeia. USP 44. Rockville: The United States Pharmacopoeial Convention, 2021.

14. Soroush H, Ghorbani-Bidkorbeh F, Mortazavi SA, Mehramizi A. Formulation Optimization and Assessment of Dexamethasone Orally Disintegrating Tablets Using Box-Behnken Design. Iran J Pharm Res. 2018; 17(4):1150-1163. PMID: 30568675; PMCID: PMC6269575.

15. Consiglieri VO, Mourão S, Sampaio M, Granizo P, Garcia P, Martinello V, et al. Improvement of fluconazole flowability and its effect on dissolution from tablets and capsules. Braz. J. Pharm. Sci. 2010; 46(1):115-120.

http://www.scielo.br/scielo.php?script=sci_arttext\&pid $=\mathrm{S} 1984$ 82502010000100013\&lng=en. https://doi.org/10.1590/ S1984-82502010000100013.

16. Dayal P, Pillay V, Babu RJ, Singh M. Box-Behnken experimental design in the development of a nasal drug delivery system of model drug hydroxyurea: characterization of viscosity, in vitro drug release, droplet size, and dynamic surface tension. AAPS PharmSciTech. 2005; 6(4):E573-85. doi: 10.1208/pt060472. PMID: 16408859; PMCID: PMC2750605. 
17. Abbas G, Hanif M, Rasul A, Khan SM, Amir MN, Nasir B, et al. Box-behnken design: a statistical approach to evaluate the effect of crosslinked carboxymethyl cellulose and sodium starch glycolate on release kinetics of drug. Acta Pol. Pharm. 2018; 75(4):965-975.DOI: 10.32383/appdr/79424

18. Roy H, Rahaman A. Box-Behnken Design for Optimization of Formulation Variables for Fast Dissolving Tablet of Urapidil. Asian J. Pharm. 2018; 12(3):S946. DOI: 10.22377/ajp.v12i03.2632

19. Masuda T, Yoshihashi Y, Yonemochi E, Fujii K, Uekusa H, Terada K. Cocrystallization and amorphization induced by drug-excipient interaction improves the physical properties of acyclovir. Int $\mathrm{J}$ Pharm. 2012; 422(1-2):160-9. doi: 10.1016/j.ijpharm.2011.10.046. Epub 2011 Nov 3. PMID: 22079714.

20. Vaithianathan S, Haidar SH, Zhang X, Jiang W, Avon C, Dowling TC, et al. Effect of Common Excipients on the Oral Drug Absorption of Biopharmaceutics Classification System Class 3 Drugs Cimetidine and Acyclovir. J Pharm Sci. 2016; 105(2):996-1005. https://doi.org/10.1002/jps.24643

21. Ansel HC, Allen Jr. LV, Popovich NG editors. Formas Farmacêuticas e Sistemas de Liberação de Fármacos. 8th ed. Porto Alegre: Artmed, 2007.

22. Scheshowitsch K, Pereira A, Cruz A, Silva MAS, Stulzer HK. Avaliação da Qualidade e Perfil de Dissolução de Capsulas Manipuladas de Piroxicam. Lat. Am. J. Pharm. 2007; 26(5): 645-51. Available from: http://www.latamjpharm.org/Subscription required

23. Baracat MM, Montanher CLS, Kubacki AC, Martinez RM, Zonta GAN, Duarte JC, Nery MMF, Gianotto EAS, Georgetti SR, Casagrande R. Avaliação da Qualidade de Formulações Manipuladas e Industrializadas de Sinvastatina. Lat. Am. J. Pharm. 2009; 28(3): 427-32. http://www.latamjpharm.org/trabajos/28/3/LAJOP_2 8_3_1_15_52H4GUF7PZ.pdf 